\title{
PRINSIP DASAR TEKNOLOGI OKSIDASI MAJU : TEKNOLOGI HIBRIDA OZON DENGAN TITANIA
}

\author{
Widdi Usada, Agus Purwadi \\ Pusat Teknologi Akselerator dan Proses Bahan - BATAN
}

\begin{abstract}
ABSTRAK
PRINSIP DASAR TEKNOLOGI OKSIDASI MAJU:TEKNOLOGI HIBRID OZON DENGAN TITANIA. Salah satu masalah dalam kesehatan lingkungan adalah limbah cair organik yang berasal dari berbagai sumber pencemaran. Teknologi yang ramah lingkungan untuk degradasi limbah organik adalah ozon. Ozon ini dihasilkan melalui teknologi lucutan plasma, tetapi kemampuannya terbatas. Oleh karena itu diperlukan teknologi baru yang ramah lingkungan yang mempunyai kemampuan lebih kuat. Teknologi baru ini disebut teknik oksidasi maju. Teknologi oksidasi maju merupakan gabungan antara teknologi ozonisasi, peroksida, sinar UV dan fotokatalis. Dalam makalah ini dikenalkan prinsip dasar hibrid antara ozon dengan fotokatalis semikonduktor titania. Kemampuan pendegradasian limbah cair organik lebih kuat karena adanya radikal baru yang dihasilkan reaksi pasangan hole dan elektron dari fotokatalisator titania dengan air atau oksigen. Selanjutnya radikal baru ini akan mendegradasi limbah cair tersebut. Teknologi ini digunakan untuk mendegradasi fenol.
\end{abstract}

Kata Kunci : plasma, ozon, oksidasi maju, semikonduktor, titania, fotokatalis, sinar uv, limbah organik, kesehatan, lingkungan

\section{ABSTRACT}

BASIC PRINCIPLE OF ADVANCED OXYDATION TECHNOLOGY : HYBRID TECHNOLOGY BASED ON OZONE AND TITANIA. One of problems in health environment is organic liquid waste from many pollutant resources. Environmental friendly technology for degrading this waste is ozone which produced by plasma discharge technology, but its capability is limited. However, it is needed a new environmental friendly technology which has stronger capability. This new technology is so called advanced oxydation technology. Advanced oxydation technology is a hybrid of ozone, peroxide, UV light and photocatalyst. In this paper, it is introduced basic principle of hybrid of ozone and titania photocatalyst semiconductor. The capability of organic liquid degradation will be stronger because there is new radical which is produced by chemical reaction between electron-hole pair from photocatalyst titania and water or oxygen. This new radical then degrades this organic pollutant. This technology is used to degrade phenol.

Keywords : plasma, ozone, advanced oxydation, semiconductor, titania, photocatalyst, UV light, organic waste, health, environment.

\section{PENDAHULUAN}

Dengembangan industri yang mencakup semua sektor kehidupan merupakan kebijakan strategis yang diambil hampir semua negara. Jumlah dan kualitas produk yang tinggi dari sebuah industri menjadi parameter kemajuan suatu negara. Berkembangnya sebuah kawasan industri tidak lepas dari peranan teknologi yang semakin canggih. Pertumbuhan industri yang meningkat tajam menuntut adanya sistem produksi yang lebih efisien di seluruh sektor kegiatan. Di samping menghasilkan produk yang berguna bagi pemenuhan kebutuhan konsumen, industri juga memberikan berbagai efek samping baik dalam proses maupun produk proses terutama yang berkaitan dengan masalah limbah. Sumber limbah berbahaya berasal dari pencemaran yang diakibatkan oleh kandungan logam-logam berat dan senyawa organik yang tinggi. Bahan pencemar dalam limbah yang mengandung logam-logam berat, seperti $\mathrm{Hg}, \mathrm{Pb}, \mathrm{Cr}$, dan $\mathrm{Cu}$, sedangkan limbah dengan kandungan senyawa organik seperti dioksin, fenol, benzena, dan DDT (dichlorodiphenyl trichloroetana) yang diukur dalam nilai BOD, COD, TDS, TSS.

Pembuangan limbah yang tidak terkendali akan berakibat pada kerusakan lingkungan, matinya biota, pertumbuhan bakteri tidak terkendali, penurunan produksi baik hewani maupun nabati, dan berujung pada penurunan penyehatan lingkungan oleh karena itu perlu diambil langkah-langkah strategis untuk menangani persoalan di atas. Beberapa waktu yang lalu senyawa khlor sebagai oksidator banyak dimanfaatkan tetapi hasil penelitian tentang dampak buruk khlor sebagai salah satu senyawa bersifat karsinogen. Sebagai gantinya adalah 
digunakannya ozon karena ozon umur paronya pendek dan hasil peluruhannya adalah oksigen yang dianggap ramah lingkungan. Namun karena berbagai keterbatasan yang ada pada ozon, diperlukan peningkatan kinerja oksidator dengan resiko sekecil mungkin dan teknologi tersebut dikenal sebagai teknologi oksidasi maju. ${ }^{[1,2]}$

\section{TEORI DASAR OKSIDASI}

\section{Oksidasi Sederhana Dengan Ozon}

Ozon adalah salah satu degradan yang efektif dalam reaksi terhadap hampir semua senyawa organik. Ozon dihasilkan dengan teknologi lucutan plasma. Gambar 1 memperlihatkan teknologi lucutan plasma terhadap udara yang diubah menjadi molekul ozon.

Reaksi pembentukan ozon dengan teknologi lucutan plasma diperlihatkan sebagai berikut

$$
\mathrm{e}+\mathrm{O}_{2} \rightarrow 2 \mathrm{O}
$$

$$
\mathrm{O}+\mathrm{O}_{2} \rightarrow \mathrm{O}_{3}
$$

Ozon ini mempunyai potensial oksidasi sekitar $2.07 \mathrm{eV}$ sehingga cukup kuat untuk merusak ikatan kimia molekul organik.

\section{Oksidasi Maju ${ }^{[4]}$}

Oksidasi maju bertujuan untuk memperoleh oksidator kuat yang ramah terhadap lingkungan dan kesehatan. Untuk mendasari pemilihan teknologi baru tersebut Tabel 1 memperlihatkan beberapa oksidator dengan energi potensialnya.

Tabel 1. Jenis radikal dan potensialnya.

\begin{tabular}{|l|c|}
\hline \multicolumn{1}{|c|}{ Jenis Radikal } & Potensial (V) \\
\hline Fluorin $(\mathrm{F})$ & 2,87 \\
\hline Radikal hidroksil $(\mathrm{OH})$ & 2,86 \\
\hline Atom oksigen $(\mathrm{O})$ & 2,42 \\
\hline Molekul ozon $\left(\mathrm{O}_{3}\right)$ & 2,07 \\
\hline Hidrogen peroksida $\left(\mathrm{H}_{2} \underline{\mathrm{O}}_{2}\right)$ & 1,78 \\
\hline Khlorin $(\mathrm{Cl})$ & 1,36 \\
\hline Khlorin dioksida $\left(\mathrm{ClO}_{2}\right)$ & 1,27 \\
\hline Molekul oksigen $\left(\mathrm{O}_{2}\right)$ & 1,23 \\
\hline
\end{tabular}

Terlihat pada Tabel 1 bahwa satu-satunya radikal yang kemampuannya lebih tinggi daripada ozon dan tidak toksik adalah radikal hidroksil $(\mathrm{OH})$, sehingga usaha terfokus pada teknologi yang mampu menghasilkan radikal hidroksil tersebut, yang dikenal dengan teknologi oskidasi maju. Beberapa teknologi oksidasi maju dapat diinformasikan sebagai berikut :

a. Oksidasi maju dengan memanfaatkan sinar UV dan hidrogen peroksida $\left(\mathrm{UV}-\mathrm{H}_{2} \mathrm{O}_{2}\right)$

Dengan adanya hidrogen peroksida maka pembentukan radikal terjadi karena reaksi hidrogen peroksida dengan sinar UV dengan energi hu

$$
\mathrm{H}_{2} \mathrm{O}_{2}+h u \rightarrow 2^{*} \mathrm{OH}
$$

b. Oksidasi maju dengan memanfaatkan sinar UV dan ozon $\mathrm{O}_{3}\left(\mathrm{UV}-\mathrm{O}_{3}\right)$

Reaksi pembentukan radikalnya adalah

$$
\mathrm{O}_{3}+\mathrm{hU}+\mathrm{H}_{2} \mathrm{O} \rightarrow \mathrm{H}_{2} \mathrm{O}_{2}+\mathrm{O}_{2}
$$




$$
\mathrm{H}_{2} \mathrm{O}_{2}+h \mathrm{hu}{ }^{*} \mathrm{OH}
$$

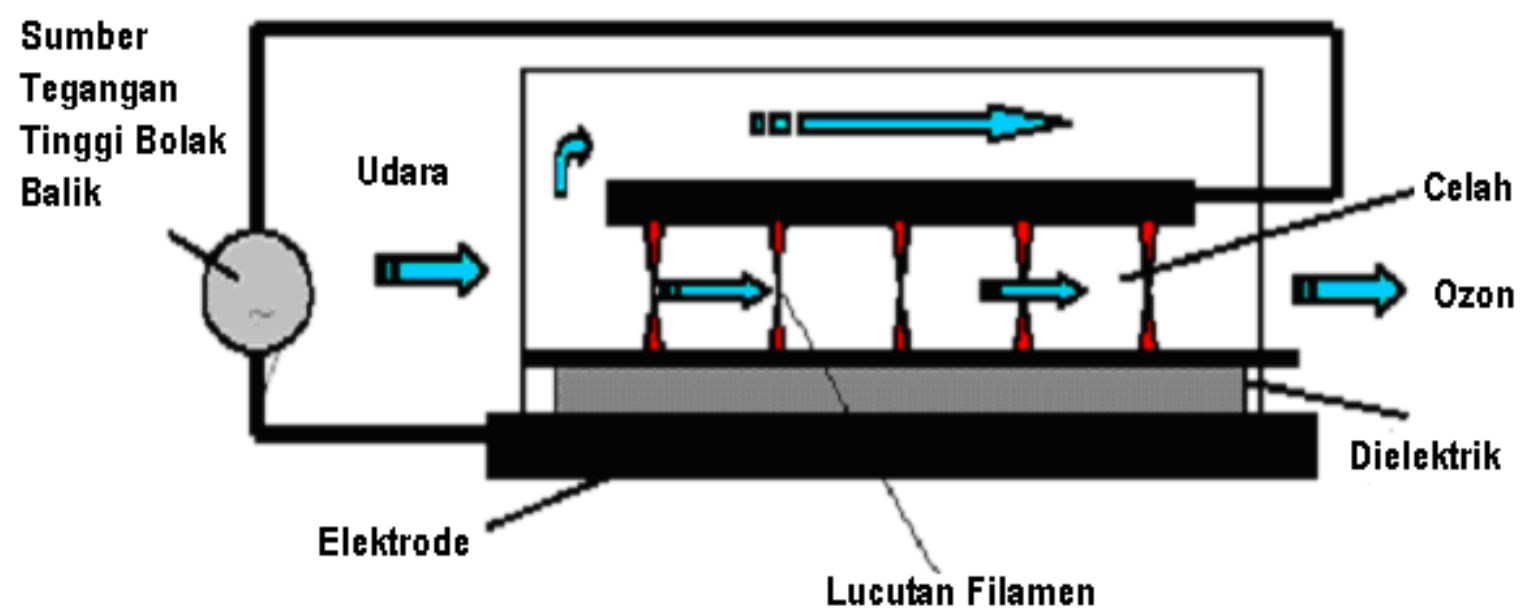

Gambar 1. Teknologi lucutan plasma penghasil ozon ${ }^{[3]}$

c. Oksidasi maju dengan memanfaatkan sinar UV, $\mathrm{H}_{2} \mathrm{O}_{2}$ dan $\mathrm{O}_{3}$

Reaksi pembentukan radikal adalah gabungan dari $\mathrm{A}$ dan $\mathrm{B}$.

d. Oksidasi maju dengan sinar $\mathrm{UV}, \mathrm{TiO}_{2}$ dan $\mathrm{O}_{3}$

Radikal $\mathrm{OH}$ diperoleh dari pengaktifan titania (titanium oksida) merupakan inti utama yang dibahas dalam makalah ini.

\section{Dasar-Dasar Fisika Fotokatalitik $\mathrm{TiO}_{2}^{[5]}$}

Titania adalah semikonduktor yang mem-punyai celah tenaga yang besar. Orbital terluar yang terisi elektron untuk unsur titanium (Ti) adalah $4 s^{2}$ dan $3 d^{2}$, dan untuk unsur oksigen adalah $2 s^{2}$ dan $2 p^{4}$. Dalam titania $\mathrm{TiO}_{2}$ tersebut, ion-ion Ti berada pada susunan kristal oktahedral dan memiliki konfigurasi elektronik $\mathrm{Ti}^{4^{+}}\left(3 \mathrm{~d}^{\circ}\right)$. Dari teori orbital molekul maka pita valensi $\mathrm{TiO}_{2}$ tersusun dari orbital $2 p$ dari unsur oksigen yang bergabung (berhibridisasi) dengan orbital $3 \mathrm{~d}$ dari unsur $\mathrm{Ti}$, sedangkan pita konduksinya tersusun murni dari orbital $3 \mathrm{~d}$ dari unsur $\mathrm{Ti}$. Bila $\mathrm{TiO}_{2}$ disinari dengan sinar UV, elektron-elektron di pita valensi tereksitasi menuju ke pita konduksi dengan meninggalkan adanya lowongan, seperti ditunjukkan pada Gambar 2.

Elektron tereksitasi di pita konduksi ini sekarang berada pada orbital $3 \mathrm{~d}$ murni dari unsur Ti dan karena sifat pita valensi dan pita konduksi sangat berbeda yaitu adanya ketidaksesuaian paritas, kebolehjadian transisi $\mathrm{e}^{-}$ menuju pita valensi berkurang sehingga mengurangi jumlah rekombinasi $e^{-}-h^{+}$. Penggambaran pita ini memberikan jaminan umur pasangan $e^{-} h^{+}$yang lama untuk terjadi difusi menuju permukaan katalis dan mengawali terjadinya reaksi redoks.

Ada tiga macam struktur kristal $\mathrm{TiO}_{2}$ yaitu (1) anatase, (2) rutile, dan (3) brookite. Energi celah pitanya untuk anatase $3.2 \mathrm{eV}$, untuk rutile $3.02 \mathrm{eV}$ dan brookite $2.96 \mathrm{eV}$. Maka untuk sinar UV dengan panjang gelombang $\lambda<385 \mathrm{~nm}$, sinar tersebut akan mampu mengeksitasi elektron e- dari pita valensi (VB = valence band) menuju pita konduksi ( $C B=$ conduction band), sehingga terbentuk pasangan $e^{-} h^{+}$. Seperti diketahui bahwa fotokatalis adalah kemampuan benda untuk mengadsorbsi secara spontan dua reaktan, yang dapat berupa reduksi dan oksidasi karena menyerap cahaya (dengan tenaga $h u>$ atau $=E_{g}$ ). Fotokatalis juga didefinisikan kemampuan untuk memindahkan elektron dari pita konduksi ke partikel penyerap (akseptor), yang ditentukan oleh posisi pita tenaga semikonduktor dan potensial redoks dari adsorbate.

Gambar 2 memperlihatkan skematis proses utama yang terjadi pada bahan semikonduktor. (a) Terjadi serapan cahaya dan pembentukan pasangan hole-elektron serta migrasi hole-elektron: anak panah (1) dan (2) memperlihatkan rekombinasi elektron dan hole baik di permukaan maupun di dalam bahan, dan anak panah (3) memperlihatkan reduksi akseptor dan (4) oksidasi donor. (b) Karena serapan foton bertenaga, elektron dieksitasi dari pita valensi (VB) menuju pita konduksi (CB). Disini ada proses transfer elektron ke molekul oksigen 
membentuk radikal ion superoksida $(\cdot 0)$ dan transfer elektron dari molekul air ke hole VB membentuk radikal hidroksil $(\mathrm{OH})$.

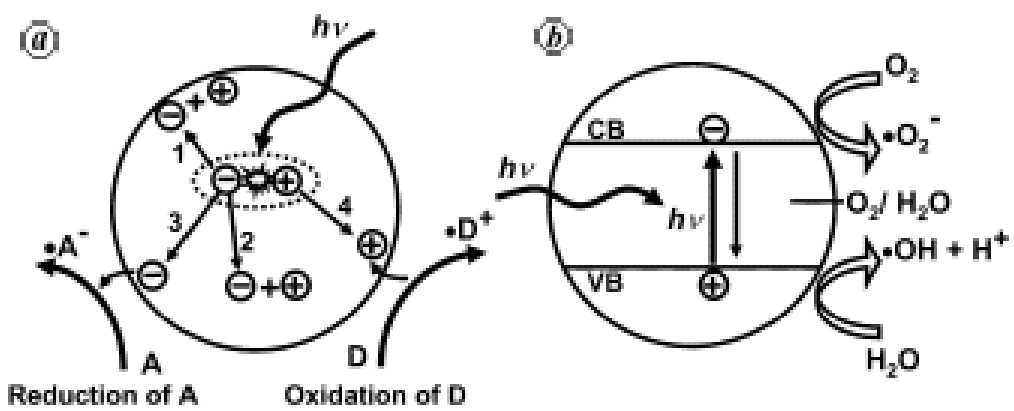

Gambar 2. Skema pembentukan radikal pada titania aktif.

Seandainya pasangan terserap tersebut adalah air dan oksigen terlarut (terdissolved) $\left(\mathrm{H}_{2} \mathrm{O} / \mathrm{O}_{2}\right)$, maka air tersebut teroksidasi oleh hole yang bermuatan positif dan ia terpecah menjadi ${ }^{*} \mathrm{OH}$ dan $\mathrm{H}^{+}$. Karena oksigen merupakan senyawa yang mudah tereduksi, maka reduksi oksigen karena fotoelektron di pita konduksi melahirkan radikal anion superoksida $\left({ }^{*} \mathrm{O}_{2}{ }^{-}\right.$), yang selanjutnya bereaksi dengan $\mathrm{H}^{+}$membentuk radikal hidrogen dioksida ( ${ }^{*} \mathrm{HO}_{2}$ atau yang disebut hidroperoksil). Terhadap tumbukan dengan elektron sehingga terbentuk anion hidrogendioksida(1-) $\left(\mathrm{HO}_{2}{ }^{-}\right.$, hidrogenperoksida(1-)), dan kemudian dengan ion hidrogen, maka terbentuk molekul $\mathrm{H}_{2} \mathrm{O}_{2}$. Rantai reaksi di atas dan reaksi-reaksi berikutnya dalam menghasilkan spesies oksigen reaktif (ROS = reactive oxygen species) seperti $\mathrm{H}_{2} \mathrm{O}_{2},{ }^{*}{ }_{2}{ }^{-}$dan sebagainya, dan radikal hidroksil "OH seperti yang dijelaskan di bawah ini. Proses fotokatalitik bermula dengan serapan foton $(h u)$ :

$$
\mathrm{TiO}_{2}+h u \rightarrow \mathrm{TiO}_{2}\left(\mathrm{e}^{-}+\mathrm{h}^{+}\right)
$$

\section{Dasar-Dasar Kimia Perusakan Senyawa Organik}

Reaksi reaksi yang terjadi di pita konduksi e-adalah

$$
\begin{aligned}
\mathrm{TiO}_{2}\left(\mathrm{e}^{-}\right)+\mathrm{O}_{2} \rightarrow \mathrm{TiO}_{2}+{ }^{*} \mathrm{O}_{2}^{-}, \\
\mathrm{TiO}_{2}\left(\mathrm{e}^{-}\right)+{ }^{*} \mathrm{O}_{2}^{-}+2 \mathrm{H}^{+} \rightarrow \mathrm{TiO}_{2}+\mathrm{H}_{2} \mathrm{O}_{2}, \\
\mathrm{TiO}_{2}\left(\mathrm{e}^{-}\right)+\mathrm{H}_{2} \mathrm{O}_{2} \rightarrow \mathrm{TiO}_{2}+{ }^{*} \mathrm{OH}+\mathrm{OH}^{-} \\
{ }^{*} \mathrm{O}_{2}^{-}+\mathrm{H}_{2} \mathrm{O}_{2} \rightarrow{ }^{*} \mathrm{OH}+\mathrm{OH}^{-}+\mathrm{O}_{2}, \\
{ }^{*} \mathrm{O}_{2}^{-}+\mathrm{H}^{+} \rightarrow{ }^{*} \mathrm{HO}_{2}, \\
\mathrm{TiO}_{2}\left(\mathrm{e}^{-}\right)+{ }^{*} \mathrm{HO}_{2} \rightarrow \mathrm{TiO}_{2}+\mathrm{HO}_{2}{ }^{-} \\
\mathrm{HO}_{2}^{-}+\mathrm{H}^{+} \rightarrow \mathrm{H}_{2} \mathrm{O}_{2}, \\
{ }^{*} \mathrm{HO}_{2} \rightarrow \mathrm{O}_{2}+\mathrm{H}_{2} \mathrm{O}_{2}
\end{aligned}
$$

Reaksi-reaksi yang terjadi di pita valensi $h^{+}$adalah

$$
\begin{aligned}
\mathrm{TiO}_{2}\left(\mathrm{~h}^{+}\right)+\mathrm{H}_{2} \mathrm{O}_{\mathrm{ads}} & \rightarrow \mathrm{TiO}_{2}+{ }^{*} \mathrm{OH}_{\mathrm{ads}}+\mathrm{H}^{+}, \\
\mathrm{TiO}_{2}\left(\mathrm{~h}^{+}\right)+2 \mathrm{H}_{2} \mathrm{O}_{\mathrm{ads}} & \rightarrow \mathrm{TiO}_{2}+2 \mathrm{H}^{+}+\mathrm{H}_{2} \mathrm{O} 2 \\
\mathrm{TiO}_{2}\left(\mathrm{~h}^{+}\right)+\mathrm{OH}_{\mathrm{ads}}{ }^{-} & \rightarrow \mathrm{TiO}_{2}+{ }^{*} \mathrm{OH}_{\mathrm{ads}},
\end{aligned}
$$


Radikal spesies oksigen reaktif dan hidroksil menyebabkan kerusakan berbagai macam komponen sel sehingga ia berperan sebagai aktivator biocidal saat diaktifkan oleh fotokatalisis. Reaksi akhir juga terjadi selama proses di atas :

$$
\begin{gathered}
{ }^{*} \mathrm{OH}+\mathrm{H}^{+}+2 \mathrm{e}^{-} \rightarrow \mathrm{H}_{2} \mathrm{O}, \\
1 / 2 \mathrm{O}_{2}+2 \mathrm{H}^{+}+2 \mathrm{e}^{-} \rightarrow \mathrm{H}_{2} \mathrm{O},
\end{gathered}
$$

Radikal bebas hidroksil "OH sangat reaktif, berumur pendek dan detrimental. la dapat menembus dinding sel dan merusak ikatan DNA. Anion superoksida " $\mathrm{O}_{2}$ ' berumur lebih panjang tetapi tidak dapat menembus dinding sel karena bermuatan negatif sedangkan hidrogen peroksida $\left(\mathrm{H}_{2} \mathrm{O}_{2}\right)$ dapat menembus dinding sel. Anion superoksida dan hidrogen peroksida keduanya reaktif terhadap molekul makro biologis dan juga berperan sebagai precursor untuk radikal hidroksil $(* \mathrm{OH})$. Rantai reaksi diatas diperlihatkan secara ilustrasi pada Gambar 2. Dengan demikian jelaslah bahwa bila digunakan gabungan antara ozon dengan titania dan sinar UV dapat diperoleh tingkat degradasi limbah organik sedemikian besar. Pendegradasian limbah organik dengan metode gabungan ini yang dikenal dengan oksidasi maju. Apabila dikenakan pada limbah maka yang terjadi adalah penurunan BOD dan COD, kadar bakteri, mikroorganisme dll. dalam limbah turun, warna dan kekeruhan limbah akan jauh berkurang.

Reaksi pada umumnya antara radikal $\mathrm{OH}$ dengan limbah organik dengan produk reaksinya dapat dirumuskan sebagai berikut,

$$
\begin{aligned}
{ }^{*} \mathrm{OH} & +\mathrm{O}_{2}+\mathrm{C}_{n} \mathrm{O}_{m} \mathrm{H}_{(2 n-2 m+2)} \rightarrow \rightarrow \rightarrow n \mathrm{CO}_{2} \\
& +(n-m+1) \mathrm{H}_{2} \mathrm{O}
\end{aligned}
$$

Degradasi limbah organik karena reaksi dengan radikal $\mathrm{OH}$ menghasilkan air dan gas karbondioksida.

\section{PEMBAHASAN}

Melalui proses oksidasi, ozon mampu membunuh berbagai macam mikroorganisme, perlakuan air minum, air limbah, sterilisasi bahan makanan mentah, dan peralatan medis. Daya degradasinya dapat dipengaruhi beberapa faktor, antara lain : pH sampel, suhu, konsentrasi, waktu , dan konsentrasi kontaminan dalam sampel.

Keunggulan ozon dalam degradasi limbah organik cair adalah ozon larut dalam air dan dapat bergerak diantara molekul cairan sehingga mempunyai interaksi cukup kuat dengan polutan terlarut dalam air tersebut, namun kelemahan ozon yang utama adalah ozon hanya bekerja untuk suasana $\mathrm{pH}$ yang tinggi, sehingga kemampuan ozon dalam mendegradasi limbah juga terbatas.

Untuk melihat kemampuan ozon dalam merusak bakteri dan virus serta mikroorganisme lainnya perlu dipahami susunan senyawa mikroorganisme serta ukuran dari mikroorganisme tersebut oleh karena itu Gambar 3 memperlihatkan ukuran partikel, atom, molekul, bakteri dan virus. ${ }^{[6]}$

Pada Gambar 3 tampak bahwa ukuran senyawa ozon sebagai molekul sederhana hanya sekitar 1/100 ukuran virus dan 1/1000 ukuran bakteri, oleh karena itu dengan energi hanya sekitar 2,07 eV, tidaklah mungkin satu buah ozon akan mampu membunuh virus ataupun bakteri, oleh karena itu ozon hanya berperan dalam merusak ikatan-ikatan organik yang ada di permukaan virus ataupun bakteri tersebut. Kemampuan ozon adalah merusak senyawa organik seperti asam asetik, aseton, formaldehide, benzene, benzyl alcohol, toluene. Dan produk reaksi ozon dengan senyawa organik di atas adalah $\mathrm{CO}_{2}, \mathrm{H}_{2} \mathrm{O}$ dan $\mathrm{O}_{2}$.

Karena kemampuan ozon terbatas maka diperlukan teknologi baru yang mampu memberikan nilai oksidasi yang tinggi dan ramah lingkungan. Gambar 4 memperlihatkan keterbatasan kemampuan ozon dibanding dengan metode oksidasi maju ( $\mathrm{AOP}=a d v a n c e d$ oxydation process) saat mendegradasi asam para-khlorobensena (parachloro-benzenic acid PCBA) pada air tanah (GW=ground water) dan air permukaan (SW=surface water $)^{[7]}$. 


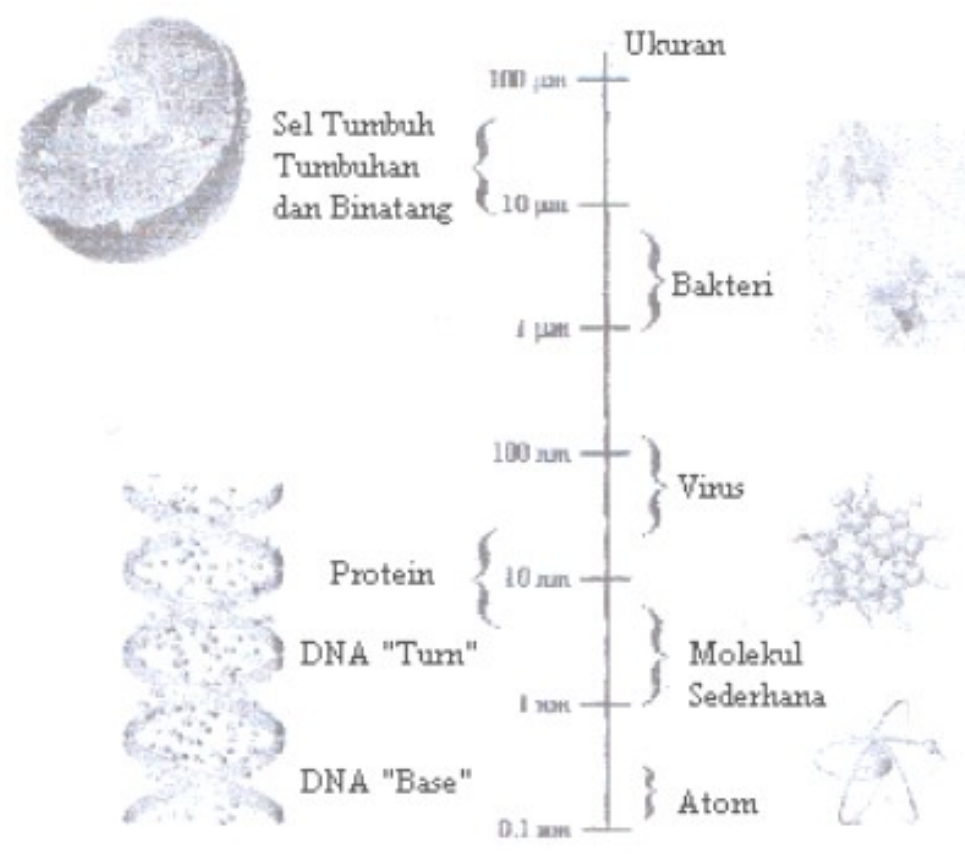

Gambar 3. Ukuran atom, molekul, bakteri dan virus.

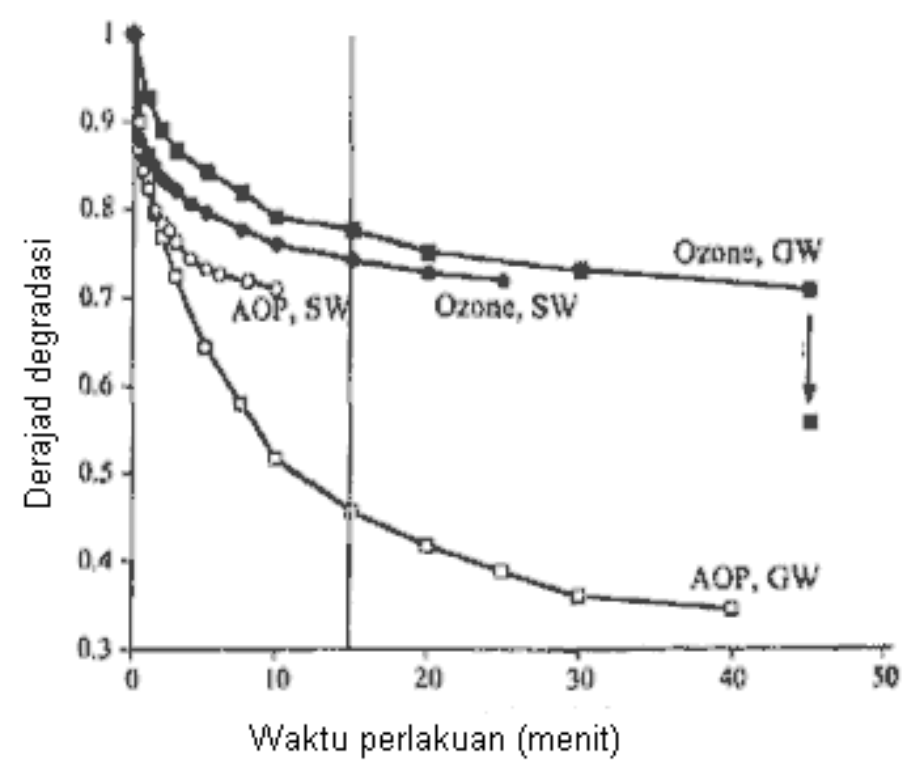

Gambar 4. Perbandingan derajad degradasi asam para khlorobensena yang terdapat pada air tanah dan air permukaan dengan teknologi ozon dan teknologi oksidasi maju. ${ }^{[4]}$

Telah diperlihatkan secara mendasar bahwa teknologi oksidasi maju khususnya penggabungan antara ozonisasi dengan UV, peroksida, dan titania sangat unggul dibanding dengan teknologi oksidasi sederhana dengan menggunakan ozon. Semikonduktor titania yang diaktifkan dengan sinar UV dan sinar tampak dibanding dengan oksidator lainnya dalam mendegradasi PCP (salah satu senyawa organik toksik) dapat diperlihatkan pada Gambar 5 dan 6 . Pada Gambar 5 cukup jelas bahwa titania lebih unggul dibanding dengan penggunaan fotokatalis lainnya apabila diaktifkan dengan sinar UV, namun tampak jelas juga bahwa bila disinari dengan sinar tampak, benar-benar titania tidak berperan, sedangkan fotokatalis lainnya unggul seperti $\mathrm{SnO}_{2} \mathrm{MoS}_{2}$ dan $\mathrm{CdS}^{[8]}$ 


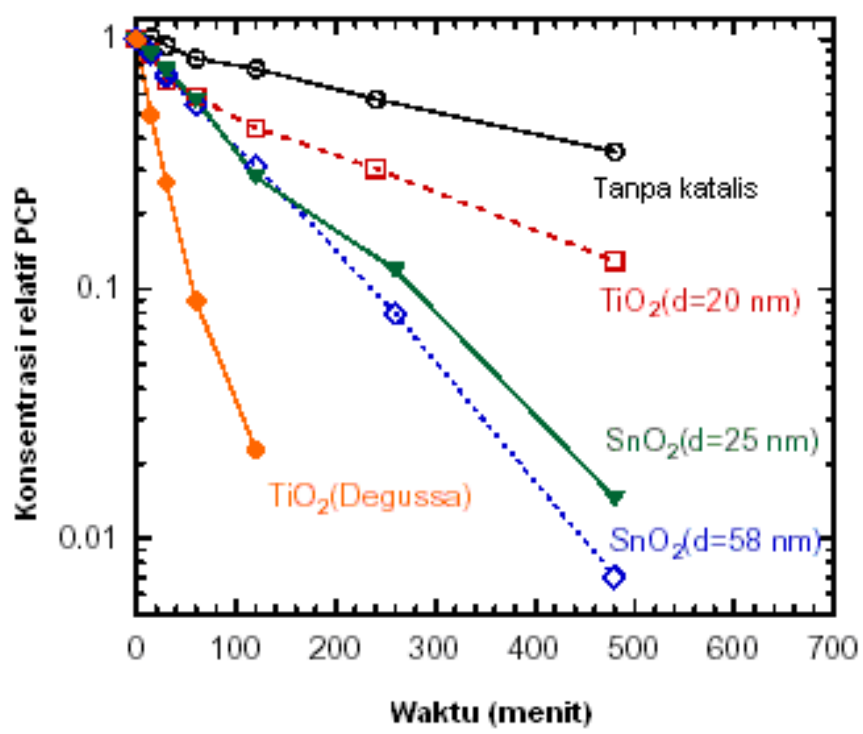

Gambar 5. Kemampuan degradasi PCP dengan beberapa fotokatalis yang diaktifkan dengan sinar UV.

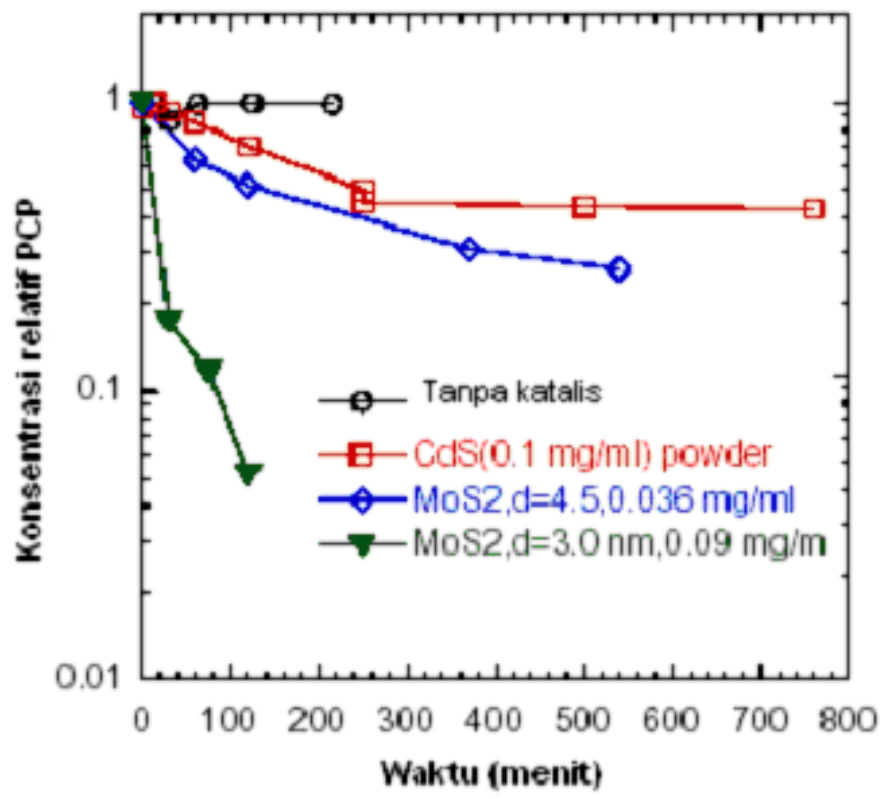

Gambar 6. Kemampuan degradasi PCP dengan beberapa fotokatalis yang diaktifkan dengan sinar tampak.

Aplikasi teknologi maju ini telah digunakan untuk mendegradasi senyawa fenol $\left(\mathrm{C}_{6} \mathrm{H}_{5} \mathrm{OH}\right)$. Beberapa alat digunakan seperti Ozonizer yang merupakan alat buatan Pusat Teknologi Akselerator dan Proses Bahan-Badan Tenaga Atom Nasional (PTAPB-BATAN) dengan spesifikasi teknis yakni tegangan $25 \mathrm{kV}$, frekuensi $1,5 \mathrm{kHz}$, daya 25 watt, dan nomor seri 007.03.06 menghasilkan output ozon sebanyak $0,00135 \mathrm{mg} /$ detik. Fotokatalis titanium dioksida $\left(\mathrm{TiO}_{2}\right)$ tipe rutil merupakan jenis bentuk allotropik dari $\mathrm{TiO}_{2}$. Sumber cahaya ultra violet (UV) dari lampu merkuri (Hg) sebesar 160 watt. Gambar 7 menunjukkan skema eksperimen.

Dengan skema eksperimen di atas maka hasil degradasi fenol karena proses ozonisasi dan pemberian titania aktif ditunjukkan Gambar 8 dan 9. ${ }^{[1]}$ 


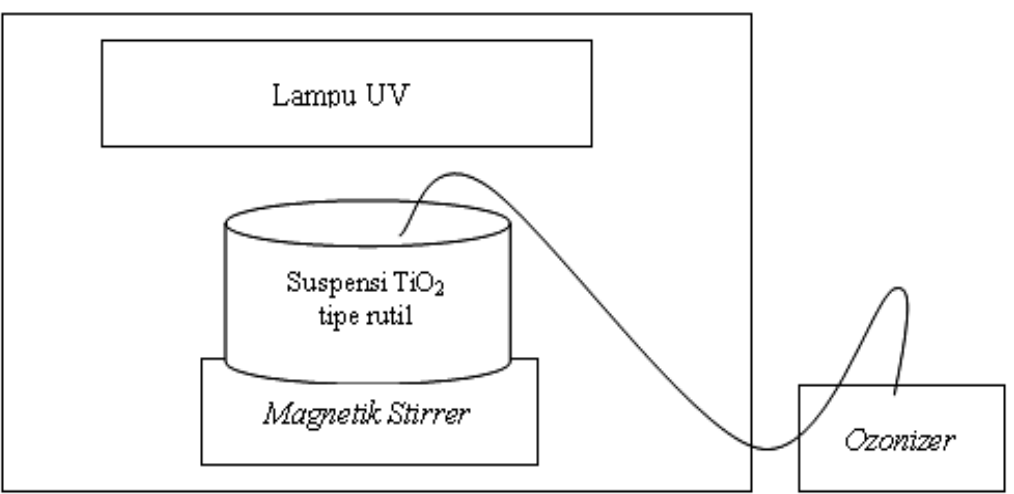

Gambar 7. Proses eksperimen degradasi fenol dengan oksidasi maju. ${ }^{[1]}$

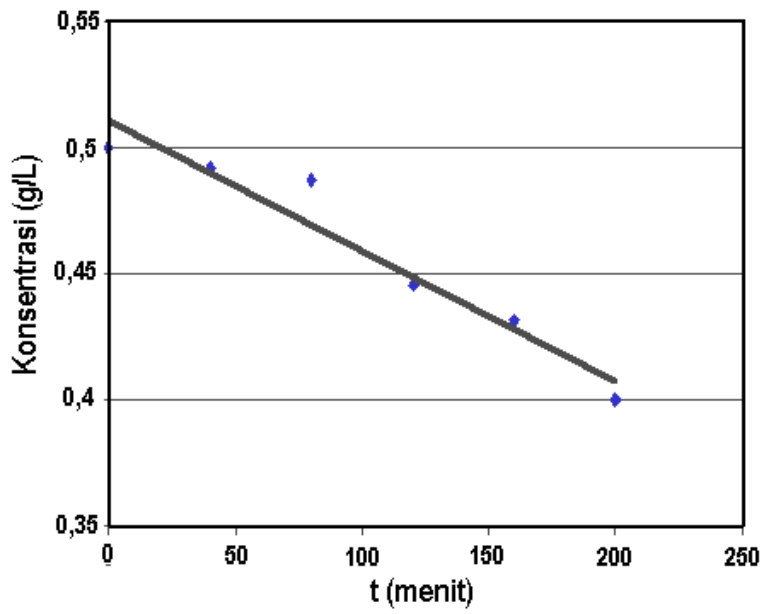

Gambar 8. Grafik penurunan konsentrasi fenol melalui reaksi ozonisasi pada berbagai variasi waktu.

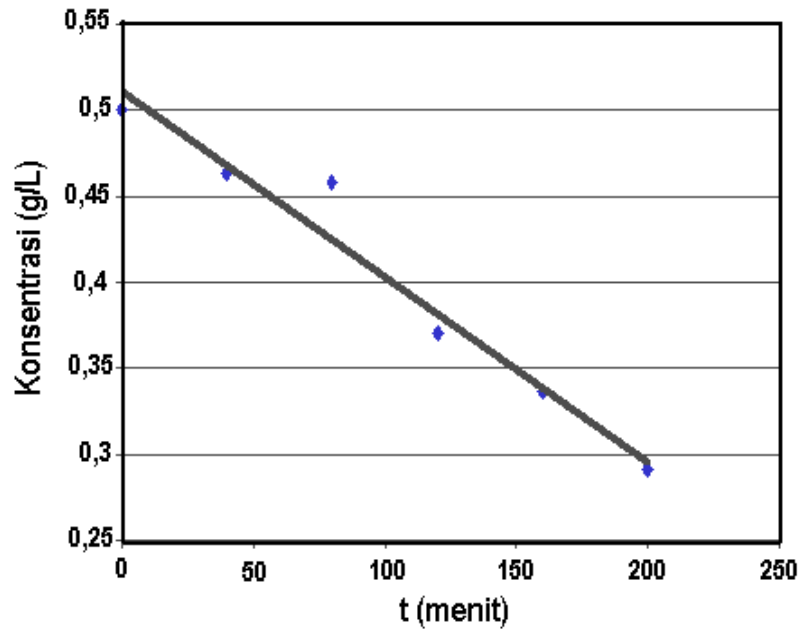

Gambar 9. Grafik penurunan konsentrasi fenol melalui reaksi ozonisasi disertai penambahan fotokatalis titanium dioksida $\left(\mathrm{TiO}_{2}\right)$ tipe rutil pada berbagai variasi waktu.

Meskipun hasil yang diperoleh belum begitu bagus tetapi tampak bahwa oskidasi maju gabungan antara ozon, UV dan titania menghasilkan derajad degradasi yang lebih unggul dibanding kalau digunakan ozon saja. Sekilas dari piranti yang digunakan jelas dengan pemakaian lampu $160 \mathrm{~W}$ akan menurunkan kinerja ozon karena 
pada suhu yang tinggi ozon cepat sekali meluruh, oleh karena itu perlu dicari sumber UV yang tidak memberikan efek panas pada saat dilakukan eksperimen.

\section{KESIMPULAN}

Telah ditunjukkan dasar-dasar fisika dan kimia baik oksidasi sederhana maupun oksidasi maju. Sebagai oksidator kuat ozon unggul karena kemampuan mobilitas yang tinggi, umur paro cukup panjang tetapi kelemahannya adalah derajad kelarutannya dalam air rendah serta energi sekitar $2.07 \mathrm{eV}$. Semikonduktor titania ternyata memperlihatkan sifat fotokatalitik saat disinari dengan UV pada energi sekitar 2.9-3.01 eV. Keunggulan titania aktif dibanding dengan ozon adalah diperolehnya radikal $\mathrm{OH}$ yang mempunyai potensial yang unggul dibanding dengan ozon sekitar $2.86 \mathrm{eV}$, namun kendalanya titania pasif sehingga untuk aktif perlu diarahkan ke sumber cahaya sehingga diperlukan alat bantu lain seperti magnetic stirrer. Meskipun unggul, oksidasi maju juga memiliki kelemahan yaitu umur paro radikal $\mathrm{OH}$ jauh lebih pendek daripada umur ozon. Untuk memperoleh sumber UV yang mempunyai intensitas tinggi dan tidak memberikan efek panas terhadap sekeliling maka dapat dicoba dengan laser nitrogen yang mempunyai panjang gelombang $337 \mathrm{~nm}$, dengan sumber cahaya baru ini diharapkan lebih banyak pasangan hole-elektron yang terbentuk sehingga pembentukan radikal $\mathrm{OH}$ semakin besar, sehingga kemampuan titania sebagai oskidator semakin besar dan karena tidak menimbulkan panas maka ozon juga dapat berfungsi maksimal.

\section{UCAPAN TERIMA KASIH}

Diucapkan terima kasih kepada Sdr. Dodi Irwanto dan Beta Agung Priyatna sebagai mahasiswa bimbingan tahun 2006 dari Jurusan Kimia UNY sehingga memaksa penulis belajar banyak tentang aplikasi oksidasi maju. Juga kepada Dr. Hari Sutrisno dosen Jurusan Kimia FMIPA UNY yang bersedia menjadi partner dalam membimbing mahasiswa tentang peranan titania untuk degradasi fenol.

\section{ACUAN}

1. DODI IRWANTO, Pengaruh Fotokatalis Titanium Dioksida $\left(\mathrm{TiO}_{2}\right)$ Tipe Rutil Dalam Reaksi Ozonisasi Terhadap Degradasi Fenol, Skripsi S1, Jur. Kimia FMIPA-UNY, 2006.

2. BETHA AGUNG PRIYATNO, Pengaruh Fotokatalis Titanium Dioksida $\left(\mathrm{TiO}_{2}\right)$ Tipe Anatas Dalam Reaksi Ozonisasi Terhadap Degradasi Fenol, Skripsi S1, Jur. Kimia FMIPA-UNY, 2006.

3. WIDDI USADA DKK., Teknologi Ozonizer, disajikan di PMBI, Februari 2007.

4. MINE DILMEGHANI and K. OMAR ZAHIR, Kinetics and Mechanism of Chloro-benzene Degradation in Aqueous Samples Using Advanced Oxidation Processes, TECHNICAL REPORT Organic Compounds in the Environment Journal of Environmental Quality 30:2062-2070, 2001.

5. BANERJEE, S., et al., Physics and chemistry of Photocatalytic titanium dioxide: Visualization of Bactericidal Activity Using Atomic Force Microscopy, CURRENT SCIENCE, VOL. 90, NO. 10, 25 MAY 2006, RESEARCH COMMUNICATIONS, PP. 1378-1383.

6. WIDDI USADA, Nanoteknologi, CARAKA NUKLIDA, Vol. 21. N0.12006.

7. LENNTECH, Ozone Reactions Mechanism, http://www.lenntech.com /feedback2.htm, 2006.

8. WILCOXON J.P. et al., Synthesis for Photo-oxidation of Toxic Organic Chemicals, Nano-structures and Advanced Materials Chemistry, e-mail address : jpwilco@sandia.gov. 